\title{
P5 -No somos botín de guerra: un análisis de la violencia sexual en el conflicto armado guatemalteco
}

\section{We are not spoils of war: an analysis of sexual violence in the Guatemalan armed conflict}

Ana Karen León Sánchez*, María Teresa Mosquera

Universidad Nacional Autónoma de México, México*

${ }^{2}$ Instituto de Estudios Interétnicos-USAC

\section{Resumen}

*Autor para correspondencia.

Correo electrónico: annielesan@gmail.com

E 1 objetivo de la ponencia es analizar las relaciones entre violencia de género y violencia política en el desarrollo de un practica social genocida reorganizadora. Se centra en analizar la transformación de las relaciones sociales a través de la violencia sexual perpetrada sobre mujeres indígenas guatemaltecas que habitaban el área noroccidental. Durante una guerra, como la que se llevó a cabo en Guatemala, la violencia de género adquiere importancia. Al incorporar el concepto de prácticas sociales genocidas, permite pensar que la violencia de género desde la política -si bien existe una tradición de pensarla desde lo político-, por ello el énfasis en conceptualizarla como violencia política de género. ¿Es que acaso la violencia ejercida en el espacio público difiere tajantemente de la violencia ejercida en el espacio privado? Reconocemos que no hay que perder de vista las especificidades pero, de igual manera, no debemos perder de vista las similitudes y continuidades. La violencia de género debe ser leída en ese sentido: el hecho de que se reproduzca en la esfera privada no significa que sea un asunto "íntimo"; así mismo, el hecho de que se reproduzca en el espacio público no significa que no tenga consecuencias en la cotidianidad que se plantean en el interior de una estructura entre unos grupos y otros. En consecuencia, al analizar los conflictos bélicos con un enfoque de género se evidencia cómo la violencia ha adoptado diversas formas a partir del reconocimiento de los referentes símbolos, como una estrategia política. Las violaciones durante la guerra no se dieron en el vacío ideológico, sino que se sustentaron en la moral sexual.

Palabras clave: genocidio reorganizador, Guatemala, mujeres, violencia política, violencia de género

\begin{abstract}
$\mathrm{T}$

he aim of the paper is to analyze the relationships between gender violence and political violence in the development of a reorganizing genocidal social practice. It focuses on analyzing the transformation of social relationships through the sexual violence perpetrated on Guatemalan indigenous women who lived in the northwestern area. During a war, like the one that took place in Guatemala, gender violence acquires importance. By incorporating the concept of genocidal social practices allows to think about gender violence from politics -though there is a tradition of thinking from the political perspective-, for that reason the emphasis on conceptualizing it as gender-based political violence.Is it that the violence exerted in the public space differs sharply from the violence exerted in the private space? We recognize that we must not lose sight of the specificities but, similarly, we must not lose sight of the similarities and continuities. Gender violence must be read in that sense: the fact that it is reproduced in the private sphere does not mean that it is an "intimate" matter; likewise, the fact that it is reproduced in public space does not mean that it does not have consequences in everyday life that arise within a structure between some groups and others. Consequently, analyzing war conflicts with a gender focus shows how violence has adopted various forms based on the recognition of symbolic referents as a political strategy. The rapes during the war did not occur in the ideological vacuum, but were based on sexual morality.
\end{abstract}

Keywords: reorganizing genocide, Guatemala, women, political violence, gender violence 


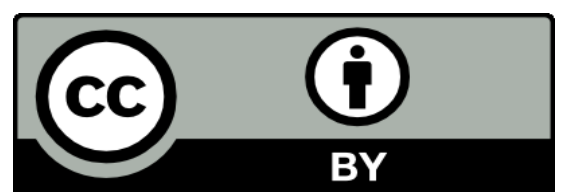

Este texto está protegido por una licencia CreativeCommons 4.0.

Usted es libre para compartir, copiar y redistribuir el material en cualquier medio o formato y adaptar el documento, remezclar, transformar y crear a partir del material para cualquier propósito, incluso comercialmente, siempre que cumpla la condición de atribución: usted debe reconocer el crédito de una obra de manera adecuada, proporcionar un enlace a la licencia, e indicar si se han realizado cambios. Puede hacerlo en cualquier forma razonable, pero no de forma tal que sugiera que tiene el apoyo del licenciante o lo recibe por el uso que hace. 